\title{
CRIME PREVENTION THROUGH ENVIRONMENTAL DESIGN IN WESTERN AUSTRALIA: PLANNING FOR SUSTAINABLE URBAN FUTURES
}

\author{
P. COZENS \\ Department of Urban and Regional Planning, Curtin University of Technology, Western Australia.
}

\begin{abstract}
Purpose: Cities as places of human habitation have multiple and interwoven impacts on the environment and upon their inhabitants. There are many definitions and interpretations of sustainable development and various models exist for the sustainable city, ranging from 'light green' to 'dark green'. This paper discusses the 'redesigning the city' model and investigates the extent to which crime and fear of crime are integrated within this framework and argues that crime prevention through environmental design (CPTED) represents a useful planning tool to assist in the development of urban sustainability. Results: A review of the literature clearly indicates that crime and fear of crime need to be considered within sustainability frameworks and that these issues can seriously undermine the broader aims of urban sustainability. If sustainability is to adequately represent the new large-scale vision to guide the planning agenda for the 21 st century, it must incorporate a primary consideration for all potential threats to the long-term sustainable health and personal safety of both the built environment and its occupants. Conclusions: The paper concludes that such issues as crime and the fear of crime are not effectively represented within most sustainability agendas, and require explicit inclusion. Analysts tend to focus on levels of recorded crime, largely ignoring the crucial and arguably more important dimension of citizens' fear of crime and their perceptions of the built environment. This paper provides recommendations for integrating crime and fear of crime within urban sustainability. It also proposes that 'designing out crime', also known as CPTED, represents a vital tool for assisting in the creation, development and promotion of more user-friendly and sustainable urban environments.

Keywords: cities, crime prevention through environmental design (CPTED), designing out crime, fear of crime, perceptions of crime, sustainability, Western Australia.
\end{abstract}

\section{INTRODUCTION}

Cities have diverse impacts on the environment and its residents in current and future generations. This paper discusses the 'redesigning the city' model for sustainable development [1] and investigates the extent to which crime and fear of crime are integrated within this framework. If sustainability is the new large-scale vision to guide the planning agenda for the 21st century [2], it must consider all potential threats to the long-term health, vitality, personal safety and security of both the built environment and its citizens. This paper discusses the pervasive issues of crime and fear of crime and the threat they both pose to the long-term sustainability, functioning, vitality and longevity of the city. Crime is included within certain sustainability frameworks, but arguably requires more explicit integration. Recorded crime statistics often represents the indicator for 'crime', and this approach is highly limited and also ignores the crucial dimension of citizens' fear of crime. Crime is highly complex and has many explanations. However, the relationship between the built environment and crime represents an issue that planners can influence directly. It is argued that crime prevention through environmental design (CPTED) is a useful planning tool for assisting in the creation of more efficient, sustainable and liveable urban design.

Indeed, in discussing human needs and sustainability, Carmona ([3], p. 183) argues that this encompasses

the need to plan ahead and consider the impact of urban design today on the experience of future generations (futurity) concerns the careful stewardship of the environment through the ability of 
projects to enhance established environments and create manageable places that people will want to look after.

CPTED is also known as 'designing out crime', and is defined by Crowe ([4], p. 1) as

the proper design and effective use of the built environment [which] can lead to a reduction in the fear of crime and the incidence of crime, and to an improvement in the quality of life.

This involves the design and management of the built environment to reduce the opportunities for crime and deviant behaviour. CPTED promotes active, mixed-use developments and works best when active community participation is recruited. This paper argues that crime and fear of crime have not been adequately integrated within the concept of urban sustainability and that CPTED is an essential tool for assisting in redefining what sustainability is, both in theory and practice. Recommendations for the development of urban sustainability protocols integrating issues such as crime, fear of crime and CPTED, are also examined.

\section{URBANISM, WELFARE AND SAFETY}

Human settlements have always sought to provide for the safety, security and the well-being of their citizens in terms of design and proximity of location to water, food and other vital resources. Safety and security have been significant issues throughout history, from early prehistoric cave-dwelling societies to medieval and modern cities. Settlements have adapted to reflect new and emerging threats as new technologies developed. A variety of fortification designs for castles such as landscaping, protective walls and moats occurred throughout the middle ages and thereafter to protect inhabitants from the threat of attack, plunder and war represented by 'others' assumed to exist beyond such perimeters. Intriguingly, Bronowski [5] has referred to war as a highly planned form of theft and as such represented a significant threat. A range of new threats to public welfare and well-being emerged as industrialisation and urbanisation progressed and the rapid, unplanned and 'laissez-faire' expansion of cities resulted in overcrowding, pollution, poverty, disease, crime and 'anomie' [6] with cities becoming containers of myriad problems as well as places of vitality, excitement and 'joie de vivre'. Indeed, as Calvino has commented,

cities, like dreams, are made of desires and fears ([7], p. 53).

In the 19th century, commentators, such as Mayhew [8] and Booth [9] among others made causal connections between crime and urban areas with poor economic, social and environmental performance. Some were dismayed and shocked at the conditions in certain parts of cities, and various 'philanthropic' visions, developments and model urbanisations were designed (e.g. Robert Owen's New Lanark, 1799; Titus Salt's Saltaire, 1853; William Lever's Port Sunlight, 1888; George Cadbury’s Bourneville in the 1890s; and Ebenezer Howard's Garden City movement, 1898).

During the public health era (19th century USA, GB and Australia), people who are affected by tuberculosis and people who engaged in criminal behaviour were both labeled as 'undesirables' and threats to the safety of the society. Moreover, as authorities tried to combat these threats to society, they began to adopt methods that would affect threats to human health and personal safety and security. Interestingly, Del Carmen and Robinson ([10], p. 267) argue:

efforts to control the spread of illness were achieved through CPTED strategies which preceded the academic writings of those considered to be the founders of CPTED.

\section{PLANNING AND SUSTAINABILITY}

Carmona [3] asserts that notions of local, social and economic sustainability can be traced back to the pioneers of the town planning movement such as Howard, Geddes and Unwin. However, he 


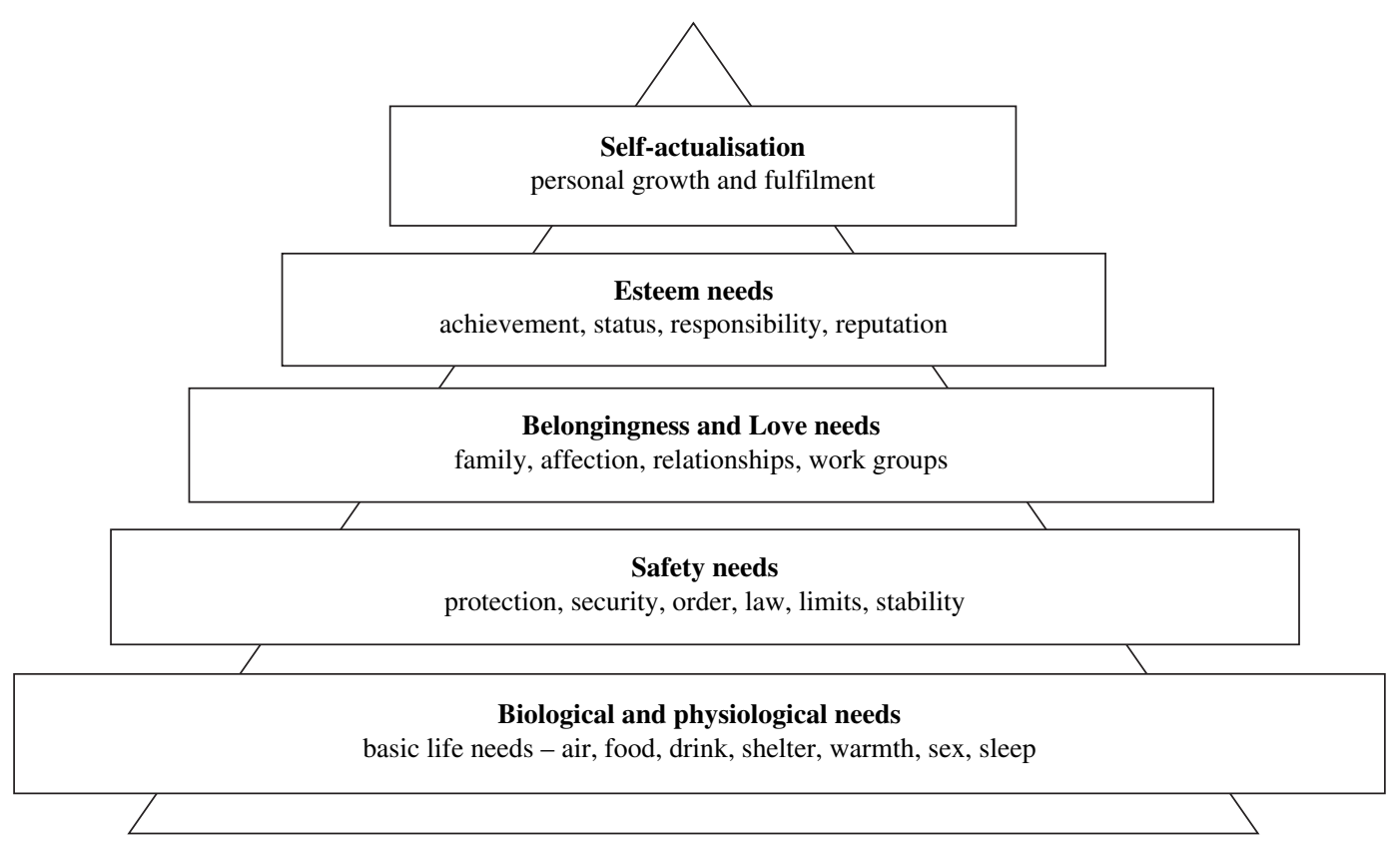

Figure 1: Maslow's hierarchy of needs. Source: Maslow [12] adapted by Chapman [13].

argues that recent writings on the concepts of sustainable development have firmly shifted towards broader environmental concerns. Many sustainability frameworks are underpinned by notions of social sustainability: equity, opportunity, quality of life and participation ([11], pp. 7-8), but few, if any, have developed sophisticated operational strategies to measure or combat crime and the fear of crime. In terms of human needs, Maslow's [12] hierarchy (see Fig. 1) suggests sustainable environments should cater for physiological needs, safety and security, affiliation (belonging and acceptance), esteem (status) and self-actualisation (expression and fulfilment).

Carmona ([3], p. 167) suggests that for urban design this involves

the creation of comfortable environments that are of human scale and visually interesting, that allow safe and crime-free human contact, movement and navigation (legibility), that are socially mixed, and that through their design and the disposition of uses are available to all.

According to Shepherd [14], the public health agenda now reflects that economic conditions, housing, education, transport and crime reduction contribute to welfare and well-being. The redrafting of the 1911 Public Health Act in Western Australia (WA) clearly reflects such thinking. Crime and public health have some commonalities [15] and both can be tackled using broadly similar approaches (e.g. improving socio-economic conditions and enhancing social capital). The effect of the built environment on crime and public health indicates that its design and modification can be used as an effective planning tool. Indeed, in a speech to the House of Commons in 1943, Churchill argued 'we give shape to our buildings, and they in turn shape us' [16].

Internationally, the environmental movement has played a central role in influencing the development of sustainability. In Australia, WA is the first state to undertake a comprehensive assessment of the implications of sustainability for government. The major objective is to embed sustainability 
into the planning system through a Sustainable Directorate in the Department of Planning and Infrastructure, devising a Sustainability Scorecard to support development control and a Sustainability and Development Assessment Committee as a Standing Committee of the Western Australian Planning Commission.

In WA, sustainable development is defined as

meeting the needs of current and future generations through an integration of environmental protection, social advancement and economic prosperity ([17], p. 12).

Figure 2 illustrates the model currently used in WA, which is influenced by the models of Barbier [18], Hancock [19] and Price [20]. Sustainability is sometimes described as the 'triple bottom line' to reflect the importance of environmental, social and economic factors in decision-making. However, the WA definition goes beyond the triple bottom line through emphasising the importance of synergistically integrating these factors.

Although there are many conceptualisations of sustainability, several recurring themes are considered as essential criteria for sustainability [21]. Gladwin et al. [22] identify inclusivity, connectivity, equity, prudence and security. It is argued that crime and the fear of crime have not been synergistically integrated within the frameworks for sustainability despite acknowledgement that:

security is an integral part of sustainability, and it is generally essential if people are to achieve their full potential ([21], p. 8).

In WA, crime and fear of crime are considered as part of the State Sustainability Strategy but references are implicit, rather than explicit [17] and it is limited to the twin principles of designing for surveillance and safety. Furthermore, there is little information concerning crime or fear of crime as indicators of sustainability and how these two issues might be defined, measured, analysed and

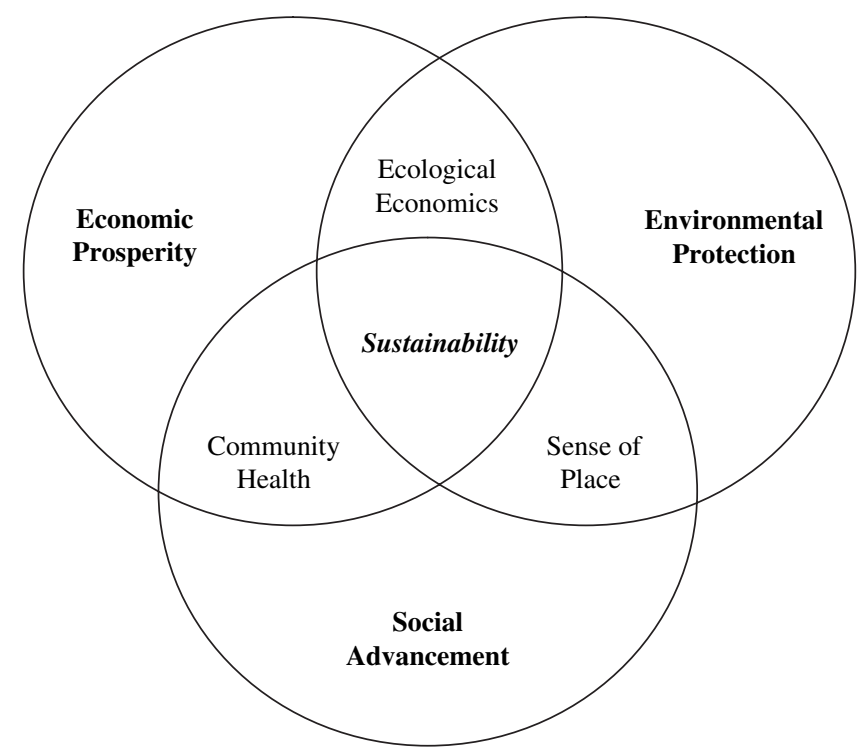

Figure 2: The Western Australian state sustainability model. Source: Government of Western Australia [17]. 
operationalised. Internationally, the two most commonly used indicators recorded are crime and the cost of crime per capita [23].

'Liveable neighbourhoods' [24] is the WA government's planning tool for achieving sustainability in urban design and was established to underpin the design and assessment of structure plans and subdivisions throughout the state. The principles are based firmly on what is known as 'new urbanism'. A growing movement of architects, planners and developers - 'new urbanism' is a reaction to urban sprawl and is based on principles of planning and architecture that work in tandem to create human-scale, walkable communities.

However, although 'liveable neighbourhoods' contributes towards promoting designing out crime, it could certainly be more explicit, and it is currently only an optional design control policy. Crucially, this planning tool unreservedly promotes walkable neighbourhoods and highly permeable urban residential layouts - which in view of current and projected increases in density levels may not operate as effectively or efficiently as they might in either British or American cities with far higher population densities and levels of activity. Crucially, commentators have noted that there are significant dangers in generalising crime and new urbanism. Indeed, Sarkissian and Kaufman ([25], p. 2) advise against opposing new urbanism.

...based on generalised and sometimes misinformed assumptions about density, rear lanes and street layout, but instead assess each of them specifically and professionally.

Research being conducted at Curtin University in WA is investigating this controversial area and the findings may have a range of implications for shaping urban sustainability agendas, new urbanism and the 'liveable neighbourhoods' programme in WA, Australia and the rest of the world.

\section{CRIME AND SUSTAINABILITY}

Such developments are certainly encouraging, but will not achieve their full potential unless they also explicitly include measures to address the ubiquitous problems of crime and the fear of crime within the community. Indeed, Du Plessis ([26], p. 33) comments:

no city can call itself sustainable if the citizens of that city fear for their personal safety and the safety of their livelihood.

Significantly, studies have repeatedly found that safety and security are often the first priority of the urban poor in both developed and developing countries [27, 28].

In Australia, the financial costs of crime to the community have been estimated to be approximately $\$ 32$ billion per annum [29] and are presented in detail in Table 1. Personal, psychological and emotional costs are clearly omitted and placing a monetary value on such issues is highly problematic.

Urban design could be potentially implicated in some of these crime including burglary and theft of vehicles estimated to cost $\$ 2.4$ billion and $\$ 880$ million per annum, respectively. Assault accounts for around $\$ 1.44$ billion while robbery in Australia costs some $\$ 600$ million per annum. The costs of fear of crime have not been evaluated although studies reveal that significant sections of the community are fearful about their personal safety and their property when using or visiting the city. For example, in 2004, in an Australian survey of 7,000 respondents, 26\% reported that they felt unsafe while walking after dark in their own neighbourhood [30] and this figure increases significantly for more vulnerable groups, such as women and the elderly. Furthermore, fear of crime increases after dark for all user groups.

There are also those who avoid using the city at certain times and some who may not use it at all. Additionally, there are also immeasurable personal, psychological and social costs attached to both 
Table 1: The estimated costs of crime in Australia.

\begin{tabular}{lc}
\hline Crime-related area & $\begin{array}{c}\text { Costs (in million Australian } \\
\text { dollar per annum) }\end{array}$ \\
\hline Costs in tackling crime & \\
Criminal justice system & 6,400 \\
Private security industry & 3,140 \\
Household precautions & 1,830 \\
Provision for victims & 880 \\
Insurance administrative costs & 500 \\
Sub-total & 12,750 \\
Costs to the community & \\
Property loss & 4,070 \\
Medical costs & 250 \\
Lost output & 2,180 \\
Intangible losses & 3,320 \\
Arson & 1,350 \\
Drugs (not elsewhere included) & 1,960 \\
Fraud & 5,880 \\
Sub-total & 19,030 \\
Total & 31,780 \\
\hline
\end{tabular}

Source: Mayhew [29].

crime and the fear of crime. Notwithstanding researchers who argue that certain urban residential designs are deterministically related to crime and criminogenesis [31], the design and management of the built environment can clearly facilitate or hinder opportunities for crime and deviant behaviour [32-40].

Within the WA Sustainability Strategy [17], it is also acknowledged that a city is an ecosystem [41]. In a city, crime and the fear of crime are interwoven within this ecosystem and the study of both environmental criminology and the 'ecology of crime' arguably warrant consideration as a central component of urban sustainability. As early as the 1920s, Park et al. [42], Burgess [43, 44] and other urban sociologists of the 'Chicago School of Human Ecology' proposed that there were interesting comparisons between the natural distribution of plant life and the organisation of human life. The 'ecology of crime' has been further developed since [33, 45-52]. Indeed, as early as 1977, Herbert ([53], p. 208) noted

as a geographical paradigm, environmentalism might have provided the most logical link to a geography of crime. That it did not do so was in part a function of scale, but more particularly of its view of the natural environment as the habitat of man.

Significantly, the situation remains unchanged in spite of the fact that $90 \%$ of the population in WA resides in 'urban' areas [17].

Planners have long been aware of sustainability issues and the application of this concept has concentrated on three key strands. Environmental sustainability involves devising and using 'best practice' in the management of energy, transport, waste and pollution. Social sustainability concerns 
the 'greening' of trade, investment and service industries and the notion of improved 'personal' responsibility for all members of a society. Finally, economic sustainability involves self-reliance and the objective of local and international, national and regional equity. Haughton [1] discusses four models that have been proposed for the sustainable city, ranging from 'light green' to 'dark green'. This paper is largely concerned with the 'redesigning the city' model which

has its roots in architectural and land-use planning perspectives, where a central theme is that redesigning the physical fabric of the existing city in various ways can encourage greater resource efficiency ([1], p. 1892).

It is argued here that the criminogenic capacity of the built environment has been largely ignored within this conceptual framework. In consideration of the predominantly urbanised character of the population in WA, environmentalists need to shift their emphasis towards embracing more energetically, 'social' and 'built' aspects of the environment and the increasingly immediate problems of parts of the inner city. However, this debate arguably dominated by today's architects and planners in pursuit of sustainability, must surely, as a priority, incorporate an understanding and consideration of crime and the fear of crime. Indeed, any neighbourhood that becomes stigmatised after only a brief period of time, and sponsors criminality by its very design and management can nurture a 'tinderbox' environment. Inappropriate tenant allocation policies and a lack of adequate property management can create a cycle of deprivation, crime and fear of crime which may exacerbate this scenario and ignite the problems of urban unrest, vandalism and even riot. Such a situation does not represent in any way a meaningful underpinning for urban sustainability.

Sustainability has been traditionally perceived as an 'environmental' or economic issue [54] which fails to consider the issues of crime and fear of crime to any meaningful extent [55,56], while others have discussed the subject minimally [57, 58]. Indeed, crime as a dimension of sustainability has only recently been subject to more widespread evaluation and discussion [26-28, 59,60] and arguably represents a dynamic addition to this evolving body of knowledge. Moreover, a recent study has highlighted crime as a major factor influencing sustainability [54]. The organic nature and our current understanding of sustainability means that the key indicators are not fixed and need to continually respond to changing circumstances, especially as our knowledge develops [61]. A consideration of CPTED strategies certainly constitutes a positive operational development of knowledge in this regard and goes beyond specifying the currently limited frameworks for sustainability which tend to focus on crime merely as an indicator of sustainability. A prerequisite for a sustainable urban environment is that it should not pose a threat to current or future users. Indeed, Dewberry [62] argues that there are various synergies between sustainable development and crime prevention including shared responsibilities, foci, objectives and approaches (see Table 2). She comments ([62], p. 53),

the levels of crime activity directly affects the degree to which we can move towards a more equitable and just society (a component of sustainability).

Although many examples of attempts at 'ecologically sustainable design' (ESD) development exist, none have evolved beyond developing primarily environmental goals. Such a focus is predominantly upon maximising efficiencies for building materials, transport, energy and water, while reducing pollution, waste, noise and impacts on the ecological diversity of the natural environment using 'whole of life thinking' for any development (e.g. the Australia Government's ESD Design Guide for Australian Government Buildings [63]). Furthermore, grandiose plans for an ESD city in China (Dontang) may result in the creation of a city which is admirably sustainable in purely environmental terms, but unsustainable socially by providing opportunities for criminality that 
Table 2: Comparisons between reducing crime and encouraging sustainability.

\begin{tabular}{|c|c|}
\hline Crime and disorder & Sustainable development \\
\hline $\begin{array}{l}\text { The need for shared responsibility } \\
\text { in tackling crime. }\end{array}$ & $\begin{array}{l}\text { The need for shared responsibility and increased } \\
\text { stakeholder involvement to move towards } \\
\text { sustainability. }\end{array}$ \\
\hline $\begin{array}{l}\text { The need for offenders to } \\
\text { acknowledge responsibility. }\end{array}$ & $\begin{array}{l}\text { The need for polluters to acknowledge } \\
\text { responsibility. }\end{array}$ \\
\hline Crime events promote social exclusion. & $\begin{array}{l}\text { The increasing gap between the security of } \\
\text { the 'haves' and the 'have nots'. }\end{array}$ \\
\hline $\begin{array}{l}\text { Reducing effects of crime through } \\
\text { investment in evidence and effectiveness. }\end{array}$ & $\begin{array}{l}\text { Reducing environmental impacts through } \\
\text { investment in evidence and effectiveness. }\end{array}$ \\
\hline $\begin{array}{l}\text { Reducing the impacts of crime through } \\
\text { developing products and systems } \\
\text { which are more resistant to } \\
\text { criminal activity. }\end{array}$ & $\begin{array}{l}\text { Moving towards sustainability through developing } \\
\text { products and systems which are more } \\
\text { environmentally and socially responsible. }\end{array}$ \\
\hline $\begin{array}{l}\text { The need for comprehensive action } \\
\text { through government strategy utilising: } \\
\text { - partnerships } \\
\text { - evidence-based action } \\
\text { - results focus - accountability }\end{array}$ & $\begin{array}{l}\text { The need for comprehensive action through } \\
\text { government strategy looking at: } \\
\text { - partnerships - increased stakeholder involvement } \\
\text { - best practice approaches - new knowledge } \\
\text { - environmental and social responsibility }\end{array}$ \\
\hline $\begin{array}{l}\text { Promoting quality of life issues, } \\
\text { e.g. enhancing liberty and rewvitalising } \\
\text { communities. }\end{array}$ & $\begin{array}{l}\text { Understanding quality of life issues, e.g. enhancing } \\
\text { equity, liberty and diversity, and revitalising } \\
\text { communities. }\end{array}$ \\
\hline $\begin{array}{l}\text { Enhancing understanding of the ecology } \\
\text { of crime and environmental criminology. }\end{array}$ & $\begin{array}{l}\text { Enhancing understanding of the ecology of the } \\
\text { environment. }\end{array}$ \\
\hline $\begin{array}{l}\text { Use of the built environment to promote } \\
\text { liveability and reduce opportunities } \\
\text { for crime. }\end{array}$ & $\begin{array}{l}\text { Use of the built environment to promote liveability } \\
\text { and sustainability. }\end{array}$ \\
\hline
\end{tabular}

Source: Adapted from Dewberry [62].

could have been avoided. The reduction of threats to personal well-being and the environment are the objectives commonly associated with the idea of sustainability. However, in a sustainable urban environment it is also essential that the inhabitants

should not have cause for fear for their personal safety and the safety of their possessions ([26], p. 33).

However, the application of CPTED in isolation will not necessarily contribute significantly towards the wider objectives of sustainability protocols. Similarly, at present, sustainability is unlikely to have any tangible impact upon levels of crime or the fear of crime. Indeed, there may be some conflicts between CPTED and ecological sustainability [64] that need to be researched and, if necessary, resolved.

Clearly, crime, violence and anti-social behaviour are potent indicators of sustainability and threats to public welfare and well-being. An 'unsustainable' community is commonly characterised by images of poverty, homelessness and high levels of crime, fear of crime and anti-social behaviour. 
Furthermore, relying on officially derived crime statistics for the purpose of measuring sustainability could undermine such a protocol, which should arguably include indicators for fear of crime and the perceptions of different user groups within the community. The Australian Bureau of Statistics [30] estimates that the under-reporting of official crime statistics varies considerably in terms of specific crime types, further reducing the reliability of using one generic indicator for 'crime' as part of a sustainability indicator. Indeed, Brantingham et al. [65] and Vrij and Winkel [66] among others have discussed the idea that fear of crime may exist in locations which according to official statistics are low crime areas. The growth of fear of crime research has been significant [67], yet may not have been given the attention it deserves [68]. Indeed, according to many commentators the official crime statistics may represent only a fraction of total crime with the missing data simply referred to as the 'dark figure of crime' [69]. Such incidents may not be witnessed or discovered, or remain either unreported or unrecorded. Reasons for under-reporting include: a reluctance to delay one's journey, a lack of confidence that the offender will be apprehended, absence of someone to actually report the incident to, and the belief that a reported incident may not be taken seriously.

A broader consideration of environmental criminology within planning is urged by Brantingham and Brantingham ([34], p. 53) who argue

most planning proceeds with little knowledge of crime patterns, crime attractors, crime generators, the importance of edges, paths and nodes or the site specific solutions that facilitate or even encourage crime.

Du Plessis ([26], p. 38) argues that although an environmental design (in isolation) does not represent the solution to the problem of crime or guarantee that a city is sustainable, it can

create a supportive physical environment for social and economic initiatives.

\section{DESIGNING OUT CRIME}

In historical terms, by the mid-nineteenth century the mapping of the distribution and demography of crime had begun $[8,70-72]$ and there has been a long and continuous study of 'dangerous places' since. Crucially, it is evident that if the spatial distribution of offences and offenders (according to official statistics) were random, then environmental criminology and CPTED would be of no value. Indeed, crime and the fear of crime are certainly not evenly distributed throughout the city and the notion of 'hot spots' of crime has received increasing attention in recent years [73, 74]. These issues can adversely affect people's 'urban narratives', their perceptions and their behaviour and may discourage the use of some urban spaces and facilities.

Moreover, Shaftoe [75] comments

no amount of physical or environmentally sustainable measures will be of any value if people are too afraid to go out on the streets.

Following the work of several researchers [32, 33, 76-80], specific elements of urban design became widely associated with enhancing or reducing opportunities for crime. Since then, CPTED has evolved in the late 20th century into a robust sub-division within criminology - although arguably, it is by definition, multidisciplinary. Furthermore, Wilson and Kelling's highly influential 'Broken Windows' thesis [81] stressed the vital importance of maintaining the built environment as a physical indicator for levels of social cohesion, informal social control and reducing fear of crime. Subsequent work in this area has repeatedly supported these findings [66, 82-87].

CPTED has emerged in recent years as a socio-spatial perspective within both criminology and urban planning. It is subject to continuing refinement and evaluation and builds upon four key 


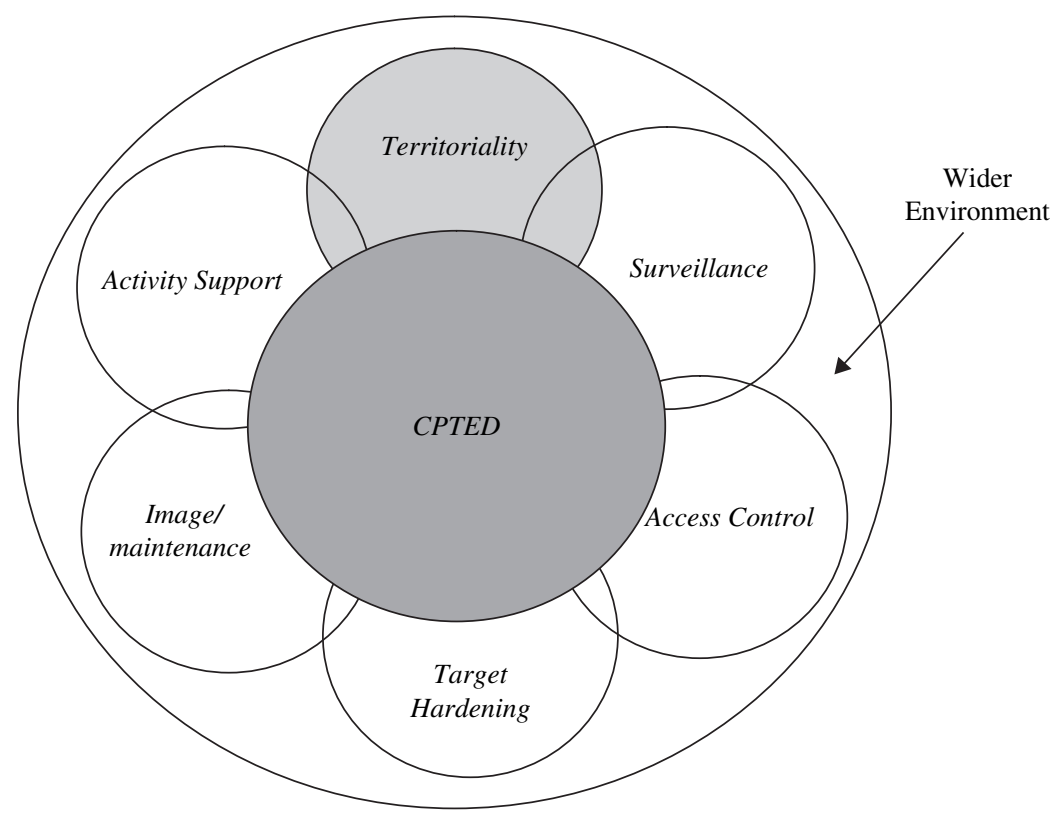

Figure 3: First generation CPTED - the key concepts. Adapted from Moffat ([88], p. 23).

strategies of territoriality, natural surveillance, activity support and access control (Fig. 3). For a more detailed discussion of CPTED see Cozens et al. [40, 89].

By optimising opportunities for surveillance, clearly defining boundaries (and defining preferred use within such spaces) and creating and maintaining a positive 'image', urban design and management can inhibit offending. This is explained by the fact that offenders are potentially more visible to 'law-abiding' others, and therefore, perceive themselves to be more at risk of observation, subsequent apprehension and punishment. Additionally, a well-maintained and appropriately used environment can signify that a sense of 'ownership' and proprietary concern exists within the community.

However, ongoing refinement, of what is now known as first generation CPTED, by researchers, practitioners and policy makers, has arguably created a more robust and rigorous approach referred to as second generation CPTED [90]. This refinement extends beyond mere physical design to include social factors. Second generation CPTED uses risk assessments, socio-economic and demographic profiling [51, 90] as well as active community participation [91-95].

A further crucial dimension concerns the effective and continuous maintenance and management of urban space that is actively being used and discouraging the under-use of such space as a result of dereliction and/or vacancy [96-98]. Furthermore, CPTED promotes higher densities, mixed-use development and activities which optimise the number of potential 'eyes on the street' [77]. Research has reported positive reductions to levels of recorded crime for CPTED-style developments in UK [99-101] and, more recently, two major reviews of CPTED have firmly demonstrated its efficacy as a crime prevention strategy $[40,102]$.

Such developments in CPTED $[4,81,93,94,103,104]$ and situational crime prevention (SCP) in Britain [37, 105-107] have popularised, refined and advanced the design-affects-crime debate. Like CPTED, SCP seeks to reduce opportunities for crime. However, it is centred upon highly specific categories of crime [37, 107] and extends beyond environmental design using specific products, 
Table 3: Twenty-five situational crime prevention techniques.

\begin{tabular}{|c|c|c|c|c|}
\hline Increase the effort & Increase the risk & $\begin{array}{l}\text { Reduce the } \\
\text { rewards }\end{array}$ & $\begin{array}{c}\text { Reduce } \\
\text { provocations }\end{array}$ & Remove excuses \\
\hline Target hardening & $\begin{array}{l}\text { Extend } \\
\text { guardianship }\end{array}$ & Conceal target & $\begin{array}{l}\text { Reduce frustration } \\
\text { and stress }\end{array}$ & Set rules \\
\hline $\begin{array}{l}\text { Control access } \\
\text { to facilities }\end{array}$ & $\begin{array}{c}\text { Assist natural } \\
\text { surveillance }\end{array}$ & Remove targets & Avoid disputes & Post instructions \\
\hline Screen exits & $\begin{array}{l}\text { Reduce } \\
\text { anonymity }\end{array}$ & Identify property & $\begin{array}{l}\text { Reduce } \\
\text { emotional arousal }\end{array}$ & Alert conscience \\
\hline Deflect offenders & $\begin{array}{l}\text { Utilise place } \\
\text { managers }\end{array}$ & Disrupt markets & $\begin{array}{l}\text { Neutralise } \\
\text { peer pressure }\end{array}$ & Assist compliance \\
\hline $\begin{array}{l}\text { Control } \\
\text { tools/weapons }\end{array}$ & $\begin{array}{l}\text { Strengthen formal } \\
\text { surveillance }\end{array}$ & Deny benefits & $\begin{array}{l}\text { Discourage } \\
\text { imitation }\end{array}$ & $\begin{array}{l}\text { Control drugs } \\
\text { and alcohol }\end{array}$ \\
\hline
\end{tabular}

Adapted from Cornish and Clarke [108].

technology and procedures to reduce opportunities for crime. SCP [108] utilises 25 techniques in five broad categories with the objective of increasing perceived effort, increasing perceived risks, reducing anticipated reward, reduce provocation and remove excuses (see Table 3).

Some researchers [109] have introduced a threefold grouping of physical features - prospect (for the user), refuge (for the potential offender) and escape (for the user and potential offender) into the CPTED theory. Taylor and Harrell ([36], p. 9) suggest, 'research confirms that fear [of crime] is higher in locations that offer good refuge for the potential offender but low prospect and escape for the user'.

Second generation CPTED includes social factors as well as physical design to enhance community cohesion and the self-policing potential of residents. Important issues include designing humanscale communities with urban meeting places, providing youth clubs, resident participation and resident responsibility. Saville and Cleveland [110] suggest, 'second generation CPTED is a new form of ecological, sustainable development. This ecological and sustainable development must of course, use traditional CPTED design principles'.

The impact and scope of CPTED is certainly evident in the recent emergence of ideas regarding the synergies between CPTED and urban sustainability [26-28, 59, 60]. Indeed, residents of crimeridden communities often experience some of the most severe environmental and social problems. A sustainable community must therefore be one that is defined as safe, perceives itself to be safe and is considered by others to be safe. Arguably, the standardisation of CPTED concepts in planning processes could avoid the repetition of some of the 'unsustainable' design failures of the recent past and contribute towards the development of 'urban environmentalism' for the 21st century [59].

Furthermore, it has been observed [111-113] that courts in America are increasingly holding landlords and others 'liable for failing to take sufficient security precautions to prevent criminal attack on their invitees, tenants and guests' ([111], p. 106). Such cases have resulted in CPTED specialists being called upon to act as expert witnesses, where design is implicated as a causal factor. This trend is likely to migrate to Britain [114] and potentially, could have a significant, far-reaching impact elsewhere. Significantly, some nations/states (e.g. UK and some American and Australia states) have begun to create/amend existing legislative and planning policy frameworks to incorporate CPTED practice and procedures into the planning process.

Significantly, at the national level the Australian and New Zealand Crime Prevention Senior Officers Group (formerly the Ministerial Forum) has endorsed CPTED codes and principles and all 
Table 4: Five goals of preventing crime.

1. Supporting families, children and young people

2. Strengthening communities and revitalising neighbourhoods

3. Targeting priority offences

4. Reducing repeat offending

5. Designing out crime and using technology

Source: Office of Crime Prevention [115].

the states are implementing such programmes. This high-level national body is also seeking to amend the Australian Building Codes and develop training and awareness-raising programmes. The WA Government is actively supporting CPTED and has established a Designing Out Crime Unit at the Office of Crime Prevention. Indeed, designing out crime is one of the five goals (Table 4) in Preventing Crime, the State's Community Safety and Crime Prevention Strategy [115].

These goals are underpinned by a series of priority actions, and a new strategic implementation framework based on partnerships which were established to ensure that these actions are met effectively and efficiently. The strategy is guided by the principles of sustainability, working cooperatively, inclusiveness, targeted efforts, evidence-based decision-making, a focus on results, and sharing knowledge. Clearly, goals that are numbered 2 and 5 of preventing crime have direct designing out crime implications.

In common with sustainability, one major objective is to embed CPTED principles within the planning process and ensure that the criminogenic potential of new urban developments is critically evaluated at the initial design stage. Furthermore, various local governments (e.g. the cities of Gosnells, Perth, Rockingham and Wanneroo in WA) have recently created their own CPTED guidelines and implemented CPTED strategies. Significantly, a recent report by the Parliament of the Commonwealth of Australia entitled 'Sustainable Cities' ([116], p. 52) recognises designing out crime as a useful approach in promoting community development. Figures 4 and 5 illustrate a railway station in UK before and after the application of CPTED principles. Figure 5 demonstrates how visibility is enhanced, places of concealment are reduced and the station is more clearly defined by its re-design and the use of signage, after CPTED modifications. However, in WA, CPTED is not obligatory and developers do not legally have to meet any minimum guidelines.

\section{CONCLUSION}

In Australia, the national commitment to CPTED is arguably adopting a cautious approach in attempting to meet the needs of future generations (at least in terms of theory and policy). In WA, 375,000 new homes will be required by 2031 [17] and most of them (60\%) will be built in existing urban areas. The potential for evaluating the sustainability of new-build housing has been discussed elsewhere [117] and this remains a relatively under-researched field. The publication of Designing Out Crime Planning Guidelines supported by Planning Bulletin No. 79 [118, 119] and a State Designing Out Crime Strategy to embed such ideas within the planning process clearly represents a policy commitment to development that will tackle present needs - and acknowledges the needs of future generations. Whether practice follows theory and policy is yet to be ascertained. Indeed, in UK, similar policy support for CPTED has not resulted in its widespread adoption. Schneider and Kitchen [120] estimate that less than 3\% of all new-build housing constructed during the period 1989-1996 met Secured By Design standards (the UK's CPTED initiative). 


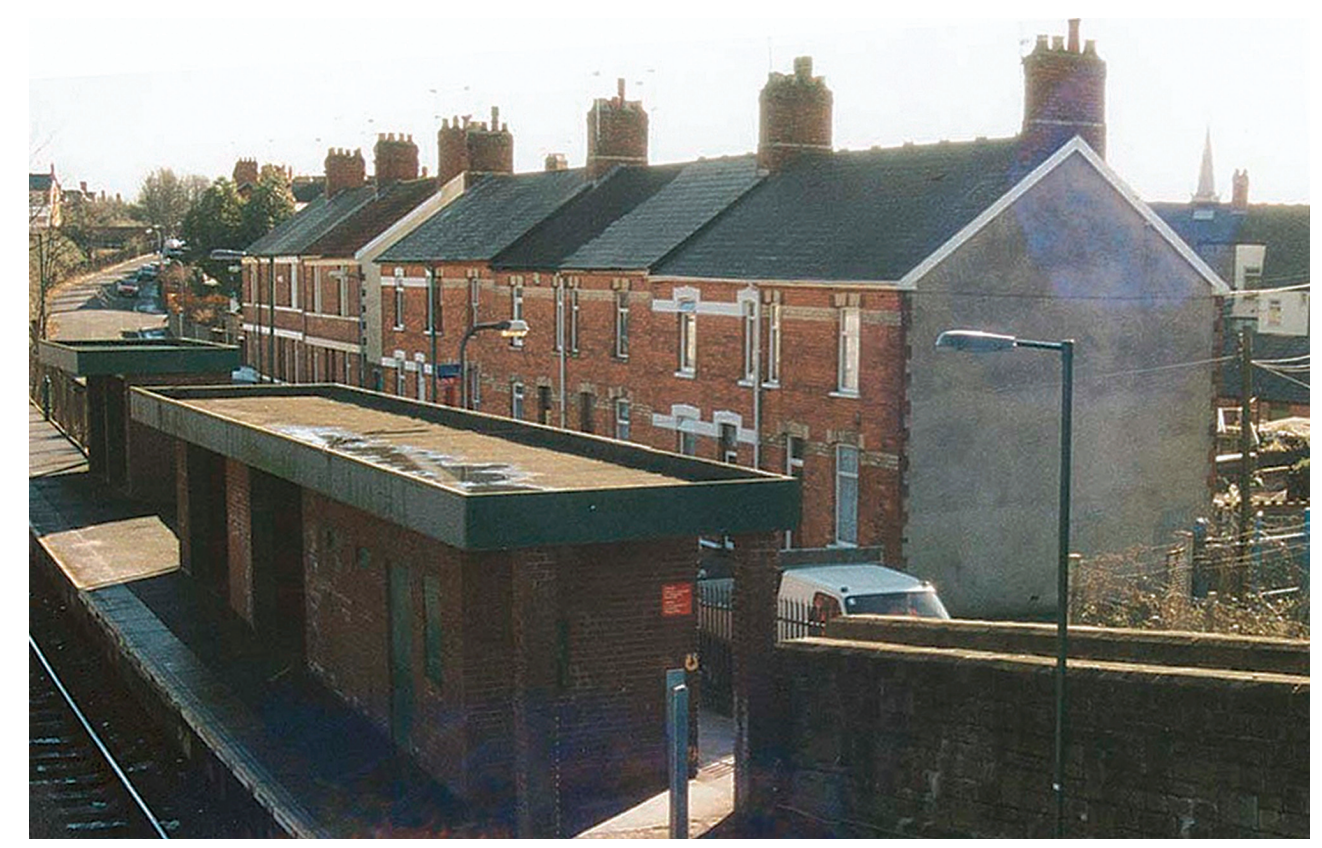

Figure 4: Railway station before CPTED modifications.

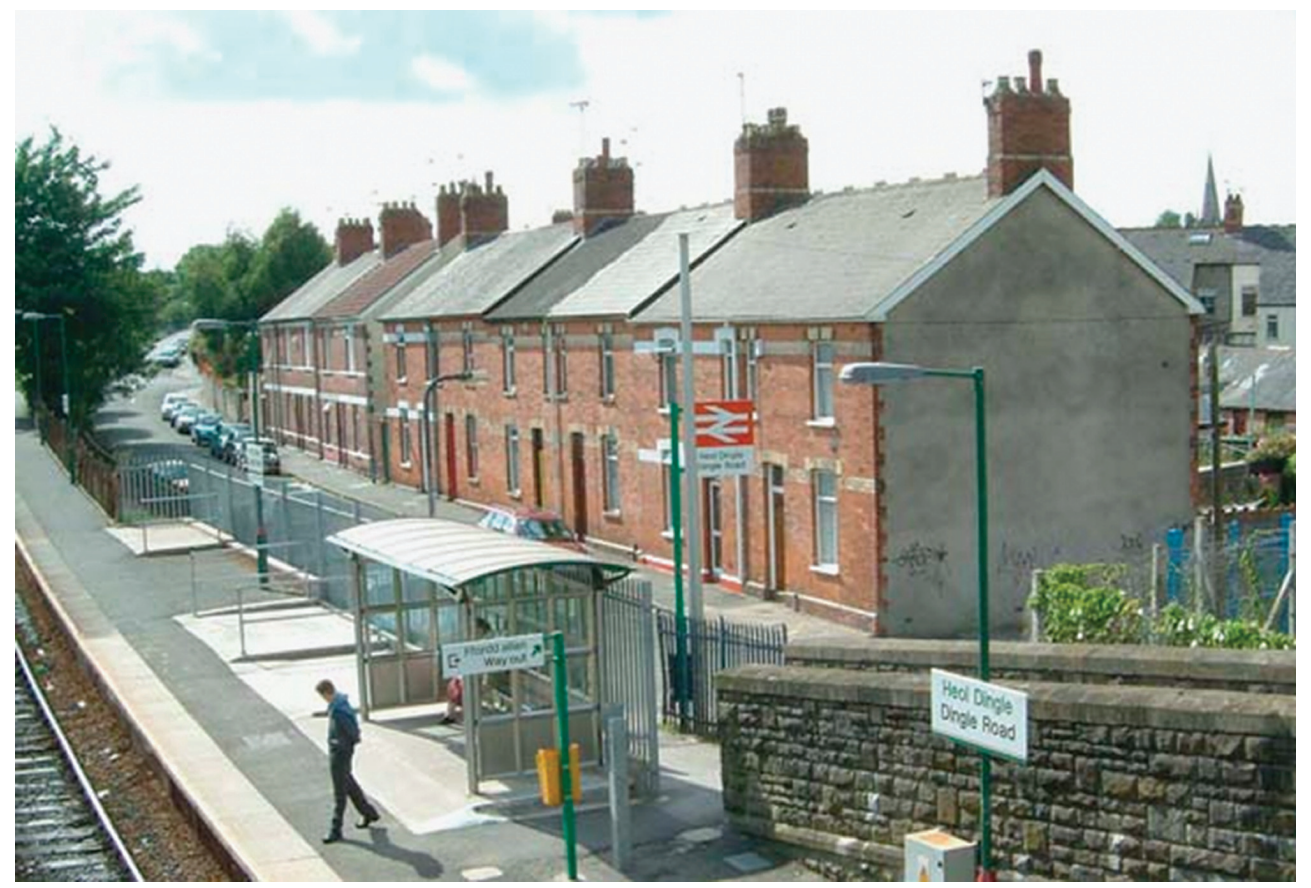

Figure 5: Railway station after CPTED modifications. 
In WA, various built environment regulations exist to protect public welfare and safety (including fire regulations) to encourage energy efficiency, reduce waste and pollution and, more recently, to promote disabled access. Moreover, some aspects of sustainability are beginning to be enshrined in law and many proposed developments are required under the Environmental Protection Act [121] to conduct an Environmental Impact Assessment (EIA). Nationally, amendments to the Building Code of Australia now ensure that all new housing will be required to meet five-star energy ratings. Notably, the potential impact on crime and the fear of crime are not part of this assessment process, despite the evidence for CPTED [99-102] and more specifically, the research on the crime-reductive effectiveness of target hardening [122-127]. Urban space which is designed to meet CPTED principles should be more 'defensible' [32] and capable of being defended by users by providing surveillance, defining territory and promoting a sense of ownership within the space. However, changing socio-economic and demographic conditions can result in the same space becoming 'undefended space' [128] where residents withdraw from the community and reduce their self-policing capabilities and responsibilities through fear of crime, for example. The process of urban decay can encourage businesses and residents to relocate, creating stigma, vacancy and dereliction. The same space can then become 'offensible space' [129] where it is defended and managed by others (e.g. drug dealers). The ecological threshold or 'tipping point' [51] of a neighbourhood is the notion that, like any natural ecosystem, it has a limited capacity for certain activities and functions (and of course, the lack of them). Clearly, the systematic and accurate monitoring of crime and fear of crime within communities across time is essential in promoting their sustainability.

Both nationally and internationally, it is arguable that sustainability frameworks do not currently possess effective indicators for crime or the fear of crime. Moreover, they fail to consider the potential impacts on crime and the fear of crime of new or existing urban developments. Crucially, crime and the fear of crime have the potential to significantly erode and reduce existing levels of sustainability within a community.

Given the synergies between crime prevention and sustainable development [62], and the significance of crime and the fear of crime, a multi-disciplinary approach is needed to debate these issues to develop research and policy and to design and monitor 'best practice' in the fields of urban sustainability and crime prevention.

In conclusion, planning can provide strategies (including CPTED) that can contribute towards creating a more sustainable community. This can be defined as the one that is safe, perceives itself to be safe and is widely considered by others to be safe. Indicators for 'crime' should be crime-type specific rather than a generic aggregation of all incidents of crime and be available at the local microlevel. Fear of crime mapping at the local level would also provide insights into devising appropriate local indicators for sustainability.

The policy support for CPTED in Australia, particularly in WA, is an encouraging use of the 'precautionary principle' within sustainability, and may help to avoid the repetition of some of the 'unsustainable' design failures of the recent past. However, without statutory support for this policy initiative, CPTED remains largely an optional and non-obligatory planning tool which in practice may not be routinely applied. CPTED is common sense, but to become a common practice, it requires that the sustainability frameworks synergistically incorporate both crime and the fear of crime.

\subsection{Recommendations for the development of urban sustainability}

- To utilise disaggregated data to analyse recorded crime at the local level and analyse specific crime-types rather than a generic category of 'crime'; 
- to develop and utilise measures of fear of crime and people's perceptions of crime at the local level and analyse specific crime-types rather than a generic category of 'crime';

- to synergistically integrate measures of crime and fear of crime as key indicators of sustainability;

- to conduct research into the process of urban decay and the 'tipping point', and measure and monitor crime and the fear of crime locally on a temporal level;

- to critically evaluate CPTED as a tool for delivering more sustainable urban communities;

- to experiment with CPTED strategies synergistically in urban developments that have conducted EIAs, ESD projects and that employ ecologically sustainable city designs;

- to conduct research into evaluating the sustainability of new-build housing using post-occupancy evaluation;

- to develop crime prevention and security rating indices for buildings and developments and integrate these into existing and developing processes for 'building sustainability' and 'green star' certification; and

- to consider integrating crime risk with the EIA process.

\section{REFERENCES}

[1] Haughton, G., Searching for the sustainable city: competing philosophical rationales and processes of 'idealogical capture' in Adelaide, South Australia. Urban Studies, 36(11), pp. 1891-1906, 1999.

[2] Berke, J., Does sustainable development offer a new direction for planning? Challenges for the twenty-first century. Journal of Planning Literature, 17(1), pp. 21-36, 2002.

[3] Carmona, M., Sustainable urban design - a possible agenda. Planning for a Sustainable Future, eds A. Layard, S. Davoudi \& S. Batty, Spon Press: London, pp. 165-192, 2001.

[4] Crowe, T., Crime Prevention through Environmental Design: Applications of Architectural Design and Space Management Concepts, 2nd edn, Butterworth-Heinemann: Oxford, 2000.

[5] Bronowski, J., The Ascent of Man, Little Brown \& Co, BBC Books: London, 1974.

[6] Wirth, L., Urbanism as a way of life. The American Journal of Sociology, 44(1), pp. 1-24, 1938.

[7] McDonough Architects. The Hanover Principles. Design for Sustainability. EXPO 2000 the World's Fair, Hanover, Germany, William McDonough and Partners: Vancouver, 1992.

[8] Mayhew, H., London Labour and the Condition of the London Poor, Griffin: Bohn, London, 1862.

[9] Booth, C., Labour and Life of the People, Williams and Norgate: London, 1889.

[10] Del Carmen, A. \& Robinson, M.B., Crime prevention through environmental design and consumption control in the United States. The Howard Journal, 39(3), pp. 267-289, 2000.

[11] CAG Consultants. Sustainability in Development Control, A Research Report, Local Government Associations: London, 1997.

[12] Maslow, A., Motivation and Personality, Harper: New York, 1943.

[13] Chapman, C., Abraham Maslow's Hierarchy of Needs Motivational Model, http://www.businessballs.com/maslow.htm, visited 21/06/06, 2002.

[14] Shepherd, J., Criminal deterrence as a public health strategy. The Lancet, 358(November), pp. 1717-1722, 2001.

[15] Kawachi, I., Kennedy, B. \& Wilkinson, R., Crime: social disorganisation and relative deprivation. Social Science and Medicine, 48, pp. 719-731, 1999.

[16] Cohen, D., Mason, K., Bedimo, A., Scribner, R., Basolo, V. \& Farley, T., Neighborhood physical conditions and health. American Journal of Public Health, 93(3), pp. 467-471, 2003.

[17] Government of Western Australia. Hope for the Future: The Western Australian State Sustainability Strategy, Department of Premier and Cabinet: Perth, 2003. 
[18] Barbier, E., The concept of sustainable economic development. Environmental Conservation, 14(2), pp. 101-110, 1987.

[19] Hancock, T., Planning and creating healthy and sustainable cities: the challenge for the 21st century. Our Cities, Our Future: Policies and Action Plans for Health and Sustainable Development, eds C. Price \& A. Tsouros, WHO Healthy Cities Project Office: Copenhagen, 1996.

[20] Price, C., (ed.), Sustainable Development and Health: Concepts, Principles and Frameworks for Action for European Cities and Towns, World Health Organisation Regional Office for Europe: Copenhagen, 1997.

[21] Black, A., The quest for sustainable healthy communities. Paper presented at the Effective Sustainability Education: What Works? Why? Where Next? Linking Research and Practice Conference, Sydney, Australia, 18-20th February 2004.

[22] Gladwin, T., Kennelly, J. \& Krause, T., Shifting paradigms for sustainable development: implications for management theory and research. The Academy of Management Review, 20(4), pp. 874-907, 1995.

[23] Hens, L. \& De Wit, J., The development of indicators and core indicators for sustainable development: a state of the art review. International Journal for Sustainable Development, 6(4), pp. 436-459, 2003.

[24] Western Australian Planning Commission (WAPC). Liveable Neighbourhoods, 3rd edn, WAPC: Perth, Western Australia, http://www.planning.wa.gov.au, 2004.

[25] Sarkissian, W. \& Kaufman, C., New urbanism and residential crime: a storm in a teacup or a real cause for alarm. Proceedings of the 9th Annual International CPTED Association Conference, Brisbane, Australia, 13-16th September 2004.

[26] Du Plessis, C., The links between crime prevention and sustainable development. Open House International, 24(1), pp. 33-40, 1999.

[27] Napier, M., Du Plessis, C., Liebermann, S., Kruger, T., Shaw, M., Louw, A. \& Oppler, S., Environmental Design for Safer Communities in South Africa, Vols 1 and 2, Council for Scientific and Industrial Research: Pretoria, 1998.

[28] Vanderschueren, F., Towards safer cities. UNCHS Habitat Debate, 4(1), 1998.

[29] Mayhew, P., Counting the Costs of Crime in Australia. Australian Institute of Criminology (AIC), Trends and Issues No. 247, AIC, Canberra, 2003.

[30] Johnson, H., Crime Victimisation in Australia: Key Results of the 2004 International Crime Victimisation Survey, Research and Public Policy Series, No. 64, 2005.

[31] Coleman, A., The crime crisis and preventable crimino-genesis. Journal of Contingencies and Crisis Management, 6(2), pp. 102-109, 1998.

[32] Newman, O., Defensible Space People and Design in the Violent City, Architectural Press: London, 1973.

[33] Brantingham, P. \& Brantingham, P., Environmental Criminology, Sage Publications: Beverly Hills, 1981.

[34] Brantingham, P. \& Brantingham, P., Environmental criminology: from theory to urban planning practice. Studies on Crime and Crime Prevention, 7(1), pp. 31-60, 1998.

[35] Ekblom, P., Less crime by design. Annals of the American Academy of Political and Social Science, 539, pp. 114-129, 1995.

[36] Taylor, R. \& Harrell, A., Physical Environment and Crime. National Institute of Justice, US Department of Justice: Washington, DC, 1996.

[37] Clarke, R., (ed.), Situational Crime Prevention: Successful Case Studies, 2nd edn, Harrow and Heston: New York, 1997. 
[38] Felson, M. \& Clarke, R., Opportunity Makes the Thief. Practical Theory for Crime Prevention, Police Research Series Paper 98, Home Office Policing and Reducing Crime Unit, Research Development and Statistics Directorate: London, 1998.

[39] Sherman, L., Farrington, D., Welsh, B. \& Mackenzie, D., Evidence-based Crime Prevention, Routledge: London, 2002.

[40] Cozens, P., Saville, G. \& Hillier, D., Crime prevention through environmental design (CPTED): a review and modern bibliography. Journal of Property Management, 23(5), pp. 328-356, 2005.

[41] Grimm, N., Grove, J., Picket, S. \& Redman, C., Integrated approaches to long-term studies of urban ecological systems. Bioscience, 50(7), pp. 571-584, 2000.

[42] Park, R., Burgess, E. \& McKenzie, D., The City, University of Chicago Press: Chicago, 1925.

[43] Burgess, E., Juvenile delinquency in a small city. Journal of American Institute of Criminal Law and Criminology, 6, pp. 724-728, 1916.

[44] Burgess, E., The growth of the city. The City, eds R.E. Park, E.W. Burgess \& D. McKenzie, University Press: Chicago, 1925.

[45] White, C., The relation of felonies to environmental factors in Indianapolis. Social Forces, 10, pp. 498-509, 1932.

[46] Lottier, S., Distribution of criminal offences in sectional regions. Journal of Criminal Law and Criminology, 29, pp. 329-344, 1938.

[47] Morris, T., The Criminal Area: A Study in Social Ecology, Routledge and Kegan Paul: London, 1957.

[48] Schmid, C., Urban crime areas: part I. American Sociological Review, 25, pp. 224-237, 1960.

[49] Schmid, C., Urban crime areas: part II. American Sociological Review, 25, pp. 655-678, 1960.

[50] Brantingham, P. \& Brantingham, P., The spatial patterning of burglary. Howard Journal, 14(2), pp. 11-23, 1975.

[51] Saville, G., Assessing risk and crime potentials in neighbourhoods. Paper presented at the 1st Annual International CPTED Association Conference, Calgary, Alberta, October 30-November 11996.

[52] Saville, G., New tools to eradicate crime places and crime/niches. Paper presented at the Safer Communities; Strategic Directions in Urban Planning Conference, Melbourne, 10-11 September, 1998.

[53] Herbert, D., Crime delinquency and the urban environment. Progress in Human Geography, 1, pp. 208-239, 1977.

[54] Knights, B., Pascoe, T. \& Henchley, A., Sustainability and Crime: Managing and Recognising the Drivers of Crime and Security, Building Research Establishment: Garston, Watford, 2002.

[55] Ravetz, J., Towards a sustainable city region. Town and Country Planning, May, pp. 152-154, 1996.

[56] Roger-Machart, C., The sustainable city - myth or reality? Town and Country Planning, February, pp. 53-55, 1997.

[57] Yiftachel, O. \& Hedgecock, D., Urban social sustainability. The planning of an Australian City. Cities, 10(2), pp. 139-157, 1993.

[58] Goodchild, B., Housing design. Urban form and sustainable development. Town Planning Review, 2(65), pp. 143-158, 1994. 
[59] Cozens, P., Sustainable urban development and crime prevention through environmental design for the British City: towards an effective urban environmentalism for the 21 st century. Cities: The International Journal of Urban Policy and Planning, 19(2), pp. 129-137, 2002.

[60] Cozens, P., Planning, crime and urban sustainability. Sustainable Development and Planing III, Vol. 1, eds A. Kungolas, C. Brebbia, \& E. Beriatos, WIT Transactions on Ecology and the Environment, WIT Press: Southampton, pp. 187-196, 2007.

[61] Department of Environment, Transport and the Regions (DETR). Monitoring Progress Indicators for the Strategy for Sustainable Development in the United Kingdom, 1999. http://environment.detr.gov.uk/sustainable/quality/monitor/index.htm

[62] Dewberry, E., Designing out crime: insights from eco-design. Security Journal, 16(1), pp. 51-62, 2003.

[63] Australian Government. ESD Design Guide for Australian Government Buildings, Department of Environment and Heritage, Canberra, 2006.

[64] Sarkissian Associates Planners. Australian Capital Territory's Crime Prevention and Urban Design Resource Manual, Department of Urban Services: Canberra, Australia, 2000.

[65] Brantingham, P., Brantingham, P. \& Molumby, T., Perceptions of crime in a dreadful enclosure. Ohio Journal of Science, 77(6), pp. 256-261, 1977.

[66] Vrij, A. \& Winkel, W., Characteristics of the built environment and fear of crime: a research note on interventions in unsafe locations. Deviant Behavior, 12, pp. 203-215, 1991.

[67] Hale, C., Fear of crime: a review of the literature. The International Review of Victimology, 4, pp. 79-150. 1996.

[68] Harries, K., Filters, fears, and photos. Speculations and explorations in the geography of crime. Analyzing Crime Patterns. Frontiers of Practice, eds V. Goldsmith, P.G. McGuire, J.H. Mollenkopf \& T.A. Ross, Sage Publications: California, 2000.

[69] Scott, J., A Matter of Record, Polity Press and Basil Blackwell Inc., 1990.

[70] Guerry, A.M., Essai sur la Statistique Morale de la France avec Cartes, Crochard: Paris, 1833.

[71] Quetelet, A., Sur L'homme et le Development de ses Facultes; Essai de Physique Sociale, Bachelier: Paris, 1835.

[72] Fletcher, J., Moral statistics of England and Wales. Journal of the Royal Statistical Society of London, 12, pp. 151-335, 1849.

[73] Nasar, J. \& Fisher, B., 'Hot spots' of fear and crime: a multi-method investigation. Journal of Environmental Psychology, 13, pp. 187-206, 1993.

[74] Lupton, D., Dangerous places and the unpredictable stranger: constructions of fear of crime. Australian and New Zealand Journal of Criminology, 32(1), pp. 1-15, 1999.

[75] Jefferson, C., Rowe, J. \& Brebbia, C., (eds), The Sustainable Street: The Environmental, Human and Economic Aspects of Street Design and Management (Advances in Architecture), WIT Press: Cambridge, Massachusetts, 2001.

[76] Lynch, K., The Image of the City, MIT Press: Cambridge, Massachusetts, 1960.

[77] Jacobs, J., The Death and Life of Great American Cities, Vintage Books: New York, 1961.

[78] Angel, S., Discouraging Crime Through City Planning, University of California Press: California, 1968.

[79] Jeffery, C., Crime prevention and control through environmental engineering. Criminologica, 7, pp. 35-58, 1969.

[80] Jeffery, C.R., Crime Prevention through Environmental Design, Sage Publications: Beverly Hills, 1971.

[81] Wilson, J. \& Kelling, G., The police and neighbourhood safety. 'Broken windows'. The Atlantic Monthly, 3, pp. 29-38, 1982. 
[82] Skogan, M. \& Maxfield, M., Reactions to Crime Project, Centre for Urban Affairs, Northwest University: Evanston, IL, 1980.

[83] Lewis, D. \& Salem, G., Fear of Crime; Incivility and the Production of a Social Problem, Transactions: New Brunswick, 1986.

[84] Nair, G., Ditton, J. \& Phillips, S., Environmental improvements and the fear of crime. British Journal of Criminology, 33(4), pp. 555-561, 1993.

[85] Kelling, G.L. \& Coles, C., Fixing Broken Windows. Restoring Order and Reducing Crime in Our Communities, Touchstone, Simon and Schuster: New York, 1996.

[86] Cozens, P., Investigating defensible space and the criminogenic capacity of characteristic British housing designs, Unpublished PhD Thesis, University of Glamorgan, 2000.

[87] Cozens, P., Hillier, D. \& Prescott, G., Defensible space: burglars and police evaluate urban residential design. Security Journal, 14(3), pp. 43-62, 2001.

[88] Moffat, R., Crime prevention through environmental design - a management perspective, Canadian Journal of Criminology, 25(4), pp. 19-31, 1983.

[89] Cozens, P., Hillier, D. \& Prescott, G., Crime and the design of residential property. Exploring the theoretical background. Property Management, 19(2), pp. 136-164, 2001.

[90] Saville, G. \& Cleveland, G., 2nd generation CPTED: an antidote to the social Y2K virus of urban design. Paper presented at the 2nd Annual International CPTED Conference, Orlando, Florida, 3-5 December 1997, www.cpted.net

[91] Plaster Carter, S., Community CPTED. The Journal of the International Crime Prevention Through Environmental Design Association, 1(1), pp. 15-24, 2002.

[92] Sarkissian, W. \& Perglut, D., The Community Participation Handbook, 2nd edn, Impact Press: Sydney, Australia, 1994.

[93] Sarkissian, W. \& Walsh, K., (eds), The Community Participation in Practice: Casebook, Murdoch University, Institute for Science and Technology Policy: Perth, Australia, 1994.

[94] Saville, G., Crime Problems, Community Solutions: Environmental Criminology as a Developing Prevention Strategy, AAG Publications, Vancouver, British Columbia, 1995.

[95] Sarkissian, W., Cook, A. \& Walsh, K., (eds), The Community Participation in Practice: A Practical Guide, Institute for Science and Technology Policy: Perth, Australia, 1997.

[96] McKay, T., Empty Spaces, Dangerous Places. International Crime Prevention Through Environmental Design Association (ICA), http://www.cpted.net/articles/empty.htm, 1999.

[97] Kraut, D., Hanging out the no vacancy sign: eliminating the blight of vacant buildings from urban areas. New York University Law Review, 74, pp. 1139-1177, 1999.

[98] Ross, C. \& Mirowsky, J., Disorder and decay: the concept and measurement of perceived neighbourhood disorder. Urban Affairs Review, 34(3), pp. 412-432, 1999.

[99] Armitage, R., An Evaluation of Secured by Design Housing Schemes Throughout the West Yorkshire Area, University of Huddersfield: Huddersfield, 1999.

[100] Brown, J., An Evaluation of the Secured by Design Initiative in Gwent, South Wales. MSc Scarman Centre for the Study of Public Order, University of Leicester, 1999.

[101] Pascoe, T., Evaluation of Secured by Design in Public Sector Housing. Final Report. Building Research Establishment: Watford, 1999.

[102] Cozens, P., Pascoe, T. \& Hillier, D., The policy and practice of secured by design (SBD). Crime Prevention and Community Safety: An International Journal, 6(1), pp. 13-29, 2004.

[103] Taylor, R.B., Gottfredson, S.D., Brower, S., Drain, W. \& Dockett, K., Toward a resident-based model of community crime prevention: urban territoriality, social networks and design. JSAS Catalog of Selected Documents in Psychology, 10, Ms. 2044, 1980. 
[104] Poyner, B., A model for action. Situational Crime Prevention: From Theory into Practice, eds K. Heal \& G. Laycock, Her Majesty's Stationery Office: London, 1986.

[105] Clarke, R. \& Mayhew, P., (eds), Designing Out Crime. Home Office and Research Planning Unit, HMSO: London, 1980.

[106] Clarke, R., (ed.), Situational Crime Prevention: Successful Case Studies, Harrow and Heston: Albany, NY1992.

[107] Clarke, R., Situational crime prevention. Building a Safer Society: Strategic Approaches to Crime Prevention, eds M. Tonry \& D. Farrington, University of Chicago Press: Chicago, 1995.

[108] Cornish, D. \& Clarke, R., Opportunities, precipitators and criminal decisions: a reply to Wortley's critique of situational crime prevention. Crime Prevention Studies, 16, pp. 41-96, 2003.

[109] Fisher, B. \& Nasar, J., Fear of crime in relation to three exterior site features: prospect, refuge and escape. Environment and Behavior, 24(1), pp. 34-65, 1992.

[110] Saville, G. \& Cleveland, G., 2nd generation CPTED: an antidote to the social Y2K virus of urban design. Paper presented at the 3rd Annual International CPTED Conference, Washington, DC, December 14-16 1998, http://www.pac2durham.com/resources/schools.pdf, visited 24th May 2007, 1998.

[111] Kennedy, D., Architectural concerns regarding security and premises liability. Journal of Architectural and Planning Research, 10(2), pp. 105-129, 1993.

[112] Gordon, C. \& Brill, W., The Expanding Role of Crime Prevention Through Environmental Design in Premises Liability. National Institute of Justice, Research Brief, US Department of Justice, Washington, DC, April 1996.

[113] Grant, S., Liability and public authorities for environmental design in Australia. Proceedings of the International CPTED Conference, September 24-27, Brisbane, Australia, pp. 303-310, 2001.

[114] Infield, P., Personal discussion, the Suzy Lamplugh trust's 'responding to Workplace violence' seminar, London Voluntary Resource Centre, Holloway, London, 10 October 2000.

[115] Office of Crime Prevention. Prevention Crime: State Community Safety and Crime Prevention Strategy, Department of Premier and Cabinet: Perth, Western Australia, 2004.

[116] Commonwealth of Australia. Sustainable Cities. The Parliament of the Commonwealth of Australia, House of Representatives Standing Committee on Environment and Heritage, Canberra, Australia, http://www.aph.gov.au/house/committee/environ/cities/report.htm, 2005.

[117] Cozens, P., Hillier, D. \& Prescott, G., The sustainable and the criminogenic. The case for new-build housing projects in Britain. Property Management, 17(3), pp. 252-261, 1999.

[118] Western Australian Planning Commission (WAPC). Designing Out Crime Guidelines, WAPC: Perth, Western Australian, 2006. http://www.wapc.wa.gov.au

[119] Western Australian Planning Commission (WAPC). Designing Out Crime Planning Bulletin No. 79, WAPC: Perth, Western Australian, 2006. www.wapc.wa.gov.au

[120] Schneider, R. \& Kitchen, T., Planning for Crime Prevention: A Transatlantic Perspective, Routledge: London, New York, 2001.

[121] Government of Western Australia. Environmental Protection Act, 1986. Government of Western Australia, State Law Publisher: Perth, WA, 1986.

[122] Allatt, P., Residential security: containment and displacement of burglary. Howard Journal of Criminal Justice, 23(1), pp. 99-116, 1984.

[123] Budd, T., Burglary of domestic dwellings: findings from the British Crime Survey. Home Office Statistical Bulletin 4/99, Home Office: London, 1999. 
[124] Knights, B. \& Pascoe, T., Burglaries Reduced by Cost Effective Target Hardening, DETR Contract Number cc1675, Building Research Establishment, Garston, 2000.

[125] Tilley, N. \& Webb, J., Burglary Reduction: Findings from Safer Cities Schemes, Crime Prevention Unit Paper 51, Home Office: London, 1994.

[126] Topping, P. \& Pascoe, T., Countering household burglary through the secured by design scheme: does it work? An assessment of the evidence, 1989-1999. Security Journal, 14(4), pp. 71-78, 2000.

[127] Tseloni, A., Wittebrood, K., Farrell, G. \& Pease, K., Burglary victimization in England and Wales, the United States and the Netherlands: a cross-national comparative test of routine activities and lifestyle theories. The British Journal of Criminology, 44(1), pp. 66-91, 2004.

[128] Merry, S., Defensible space undefended: social factors in crime prevention through environmental design. Urban Affairs Quarterly, 16(3), pp. 397-422, 1981.

[129] Atlas, R., The other side of defensible space. Security Management, pp. 63-66, March 1991. 